\title{
Factors Influencing Capital Structure of Vietnam's Real Estate Enterprises: A Move from Static to Dynamic Models
}

\author{
PHAM TIEN MINH \\ Vietnam National University, HCMC University of Technology - ptminh@hcmut.edu.vn \\ NGUYEN TIEN DUNG \\ Vietnam National University, HCMC University of Technology - ntdung@hcmut.edu.vn \\ This research is funded by HCMC University of Technology under grant number T- \\ QLCN-2014-71.
}

\section{ARTICLE INFO ABSTRACT}

Article history:

Received:

Jan. 142015

Received in revised form:

May 152015

Accepted:

04 July 2015

Keywords:

Capital structure, static model, dynamic model, GMM, real estate, speed of adjustment.
In this study, which investigates the determinants of capital structure of Vietnam's listed real estate companies, we conduct a comparative analysis of static and dynamic models, finding out several factors affecting the capital structure. By applying panel data for 47 listed companies in the real estate domain from 2008 to 2013, we find that static panel models and dynamic estimators provide significantly different results. To finally identify the capital structure determinants, we then employ the system-GMM estimation. The empirical results indicate that the pecking order theory dominates the static trade-off theory as for the Vietnam's listed real estate companies, which are also found to partially adjust their capital structure toward the target capital structure at a low speed $(\alpha=0.452)$, implying that these have to face quite large adjustment costs. 


\section{Introduction}

Recent years have marked a significant shift in the investigation of capital structure, exclusively from either static to dynamic models or basic estimates with strict hypothesis testing to advanced measures in the event of violated hypotheses.

Various studies so far conducted in Vietnam have also addressed the issue of capital structure determinants, including but not limited to Tran and Ramachandran (2006), typified by the dataset of SMEs, Vo and Bui (2012) with the case of HOSE-listed manufacturing technology enterprises, Le (2013), who attempted to analyze those listed on Vietnam Stock Market, and Le and Nguyen (2013), who examined some major building materials enterprises.

These earlier studies, except for Le and Nguyen (2013), highlighted the application of static models. In spite of their dynamic analysis, Le and Nguyen (2013) only reused the basic approaches to the static one, thus failing to completely work out such existing problems as endogeneity or autocorrelation as regards economic and/or financial modelling.

In a dire predicament surrounding the real estate sector that entails concerns of the entire economy coupled with participation of governmental agencies to surmount the hurdles, it may be necessary to probe the capital management of real estate enterprises while there remains very little empirical research into the issue.

The objectives of the present study are accordingly to: (i) extend the research from static to dynamic models using the GMM estimation, based on which it compares the cases while determining whether differences exist between the models; and (ii) conclude the determinants of capital structure reflected among real estate firms.

\section{Theoretical bases on capital structure}

Initiated by Modigliani and Miller (1958), modern theories of capital structure have been developed, notably the trade-off and pecking order theories.

The core of the trade-off theory is the balance between benefits and costs of using debt (DeAngelo \& Masulis, 1980). The use of debt helps save more and reduce taxes due to deducted repayment rates besides reducing agency costs (Jensen, 1986). Additionally, more corporate loans imply increased risk of failure to repay loans and 
interests and thereby of bankruptcy, in which case firms are to set a target leverage ratio to trade off such costs and benefits.

As regards the pecking order theory, first pioneered by Myers and Majluf (1984) and treated in detail in Myers (1984), along with asymmetric information and transaction costs, firms in need of financing give priority to the use of retained earnings, which offer the benefit of no floatation costs; next comes debt financing, and shareholders, who are finally turned to for capital funding projects.

A variety of empirical research contingent on these key theories featured the capital structure modelled as a function of firm-specific factors. Those affecting the capital structure, as indicated by earlier studies, comprise firm size, growth speed, tangible assets, profitability, risk and liquidity (Titman \& Wessels, 1988; Rajan \& Zingales, 1995; Ozkan, 2001; Chen, 2004; Frank \& Goyal, 2009). Some studies also introduced various firm-external factors such as industry effect (Hall et al., 2000) and other countryspecific factors to include GDP and capital market (Booth et al., 2001).

\section{Table 1}

Synthesis of determinants and predictions

\begin{tabular}{|c|c|c|c|c|}
\hline Variable & $\begin{array}{l}\text { Trade-off } \\
\text { theory }\end{array}$ & $\begin{array}{l}\text { Pecking } \\
\text { order } \\
\text { theory }\end{array}$ & Calculated by & Sources \\
\hline $\begin{array}{l}\text { Firm size } \\
\text { (SIZE) }\end{array}$ & + & + & Log of total assets & $\begin{array}{l}\text { Wald, 1999; Chen, 2004; } \\
\text { Chikolwa, } 2011\end{array}$ \\
\hline $\begin{array}{l}\text { Profitability } \\
\text { (PROF) }\end{array}$ & + & - & $\mathrm{EBIT} /$ total assets ratio & $\begin{array}{l}\text { Ooi, 1999; Ozkan, 2001, Gaud } \\
\text { et al., } 2005 .\end{array}$ \\
\hline $\begin{array}{l}\text { Tangible } \\
\text { assets } \\
\text { (TANG) }\end{array}$ & + & - & $\begin{array}{l}\text { (Fixed assets }+ \\
\text { investment properties } \\
+\quad \text { inventories)/total } \\
\text { assets ratio }\end{array}$ & $\begin{array}{l}\text { Chen, 2004; Gaud et al., 2005; } \\
\text { Westgaard et al., } 2008 .\end{array}$ \\
\hline $\begin{array}{l}\text { Growth rate } \\
(\text { GROW) }\end{array}$ & - & + & $\begin{array}{l}\text { Total assets } \\
\text { growth }(\% \text { per annum })\end{array}$ & $\begin{array}{l}\text { Titman \& Wessels, 1988; Ooi, } \\
\text { 1999; } \quad \text { Nguyen } \\
\text { Ramachandran, 2006. }\end{array}$ \\
\hline Risk (RISK) & - & - & $\begin{array}{l}\text { Standard deviation of } \\
\text { EBIT/total assets ratio }\end{array}$ & $\begin{array}{l}\text { Chikolwa, 2011; Graham \& } \\
\text { Leary, 2011. }\end{array}$ \\
\hline
\end{tabular}




\begin{tabular}{lcccc}
\hline Variable & $\begin{array}{c}\text { Trade-off } \\
\text { theory }\end{array}$ & $\begin{array}{c}\text { Pecking } \\
\text { order } \\
\text { theory }\end{array}$ & Calculated by & Sources \\
\hline $\begin{array}{l}\text { Liquidity } \\
\text { (LIQ) }\end{array}$ & + & - & $\begin{array}{l}\text { Current assets/short- } \\
\text { term liabilities ratio }\end{array}$ & $\begin{array}{l}\text { Rajan \& Zingales, 1995; Wald, } \\
\text { 1999; Ozkan, 2001. }\end{array}$ \\
\hline
\end{tabular}

In this study we only take note of firm-specific factors. Determinants of capital structure are as listed in Table 1, based on the two key theories and empirical research.

\section{Research data and methodology}

\subsection{Data}

The data we employ are taken from financial statements of 47 listed real estate enterprises over the period of 2008-2013. Enterprises that do not fit into HOSE- and HNX-listed real estate categories in a series of three years are excluded from the sample. However, due to insufficient information obtained from a few ones in the surveyed period, our sample features unbalanced panel data with a total of 47 firms and 269 observations.

\subsection{Research methods}

\subsubsection{Static models}

The three static panel data models that have been most commonly applied include: (i) Pooled OLS regression; (ii) fixed effects model (FEM); and (iii) random effects model (REM).

Considering the determinants of capital structure in this study allows for the following realized Pooled OLS regression:

$$
L E V_{i, t}=\beta_{0}+\beta_{I} S_{S Z E_{i, t}}+\beta_{2} P_{R O F_{i, t}}+\beta_{3} T_{A N G_{i, t}}+\beta_{4} \text { GROW }_{i, t}+\beta_{5} R I S K_{i, t}+\beta_{6} L I Q_{i, t}+e_{i, t}
$$

where $i$ is the firm itself, $t$ is year of observation, $L_{E V}$ it denotes capital structure (leverage ratio calculated by dividing total liabilities by total assets) of firm $i$ in year $t$, $\mathrm{e}_{\text {it }}$ is a normally distributed error term with the variance depending on $i$ and $t$, and SIZE $_{i t}$, $\mathrm{PROF}_{\mathrm{it}}, \mathrm{TANG}_{\mathrm{it}}, \mathrm{GROW}_{\mathrm{it}}, \mathrm{RISK}_{\mathrm{it}}$, and LIQ ${ }_{i t}$ are firm size, profitability, tangible assets, growth rate, risk, and liquidity of firm $i$ in year $t$ respectively. 
Yet, OLS regression treats firms as being homogeneous, which does not reflect the case correctly. As each should be a separate entity with its own characteristics completely different from others' such as attitudes toward risk, reputation, or management capabilities influencing capital structure, the OLS estimate may produce biased results due to its failure to control these kinds of effects.

As with FEM and REM, the effects can be properly controlled as follows : $L E V_{i, t}=\beta_{0}+\beta_{1} S I Z E_{i, t}+\beta_{2} P R O F_{i, t}+\beta_{3} T A N G_{i, t}+\beta_{4} G R O W_{i, t}+\beta_{5} R I S K_{i, t}+\beta_{6} L I Q_{i, t}+\omega_{i, t}$

where $\omega_{i, t}=v_{\mathrm{i}}+\mathrm{e}_{i, t}$, and $v_{\mathrm{i}}$ denotes separate effects of each entity $i$ which are unobserved and constant over time.

Thus, the difference between OLS regression and fixed and random effects models is the existence of $v_{i}$, whereas FEM and REM themselves differ from each other in that both accept the logical presence of $v_{i}$. However, the former would prove appropriate if there exists a correlation between $v_{\mathrm{i}}$ and independent variables, or REM is better applied in case of the correlation or $v_{\mathrm{i}} \sim\left(0, \sigma^{2}\right)$.

To decide between OLS and REM, we next conduct Breusch-Pagan Lagrange Multiplier (LM) test, while the Hausman test is considered to decide between REM and FEM.

Nevertheless, one of the disadvantages of using OLS, FEM, and REM is that these fail to address potential endogeneity, which, as observed by Getzmann et al. (2010), stems from simultaneity and omitted variables. First, the simultaneity demonstrates the likelihood of two-way causality in model (1), i.e. the leverage ratio also exerts impact on firm-specific factors, and regressing these variables would result in a correlation with random error term and thus entail endogeneity. Second, regarding omitted variables, both models (1) and (2) take no account of external factors, which are assumed to be covered by random error term and to not be related to the explanatory variables. Still, this assumption is inappropriate since random shocks external to the firm (inflation, financial crises, etc.) do affect the dependent variable (leverage ratio) and are thus likely to influence such explanatory variables as corporate performance or growth rates (Antoniou et al., 2008; Getzmann et al., 2010).

\subsubsection{Dynamic models}

While the observable leverage ratio is considered the optimum by static models, a firm's leverage ratio may be higher or lower than the target one to which the ratio will 
steadily be adjusted. Such reality can be readily grasped via dynamic models, which validate the adjustment process toward the desired capital structure, as are realized below:

$$
L E V_{i, t}-L E V_{i, t-1}=\alpha\left(L E V_{i, t}{ }^{*}-L E V_{i, t-1}\right)
$$

where $\mathrm{LEV}_{\mathrm{i}, \mathrm{t}} \& \mathrm{LEV}_{\mathrm{i}, \mathrm{t}-1}$ are actual leverage ratios of firm $i$ in year $t$ and $t-1, L E V_{i, t}{ }^{*}$ is the optimal leverage ratio of firm $i$ in year $t$, and $\alpha$ is between 0 and 1 and is inversely related to adjustment costs (Gaud et al., 2005). $\alpha>1$ implies that there is no target leverage for the firm (Antoniou et al., 2008).

From (3) we have:

$$
L E V_{i, t}=\alpha L E V_{i, t}{ }^{*}+(1-\alpha) L E V_{i, t-1}
$$

If $\alpha=1$, actual leverage ratio is equal to the optimal one $\left(L E V_{i, t}=L E V_{i, t}{ }^{*}\right)$, implying maximum adjustment can be made due to no costs borne by the firm. If $\alpha=0$, the actual ratio in the current year equals that in the previous year $\left(L E V_{i, t}=L E V_{i, t-1}\right)$, implying no adjustment is made to the optimal leverage since the costs of adjustment are enormous.

According to Ozkan (2001) and Gaud et al. (2005), the optimal leverage ratio is also a function of various determinants:

$$
\begin{aligned}
& L E V_{i, t}^{*}=\lambda_{0}+\lambda_{I} S I Z E_{i, t}+\lambda_{2} P_{R O F}{ }_{i, t}+\lambda_{3} T A N G_{i, t}+\lambda_{4} G R O W_{i, t}+\lambda_{5} R I S K_{i, t}+\lambda_{6} L I Q_{i, t}+v_{i} \\
+ & e_{i, t}
\end{aligned}
$$

Combining (4) and (5), we come up with a dynamic model of capital structure written as below :

$$
\begin{aligned}
& L E V_{i, t}=\beta_{0}+\delta L E V_{i, t-1}+\beta_{1} S I Z E_{i, t}+\beta_{2} P R O F_{i, t}+\beta_{3} T A N G_{i, t}+\beta_{4} G R O W_{i, t}+\beta_{5} R I S K_{i, t} \\
+ & \beta_{6} L I Q_{i, t}+\varphi_{i}+\varepsilon_{i, t} \\
& \text { with } \delta=(1-\alpha), \beta_{k}=\alpha \lambda_{k}(k=0-6), \varphi_{i}=\alpha v_{\mathrm{v}}, \varepsilon_{i, t}=\alpha e_{i, t}
\end{aligned}
$$

If OLS regression, FEM, or REM is used to the analyzed model (6), then the estimated results are biased and inconsistent whether the correlation between the separate effect $\varphi_{i}$ and independent variables is accepted now that the unsolved correlation between $\varepsilon_{i, t}$ and $L E V_{i, t-l}$ still exists in model (6) (Baltagi, 2008), which further causes endogeneity to the model.

To overcome these pitfalls Arellano and Bond (1991) suggested using differenced GMM, i.e. transforming model (6) into the first difference model using lags of leverage 
ratio and determinants such as instrumental variables. The differenced GMM of model (6) can be presented as follows:

$\triangle L E V_{i, t}=\delta \Delta L E V_{i, t-1}+\beta_{1} \Delta S I Z E_{i, t}+\beta_{2} \Delta P R O F_{i, t}+\beta_{3} \Delta T A N G_{i, t}+\beta_{4} \Delta G R O W_{i, t}+$ $\beta_{5} \Delta R I S K_{i, t}+\beta_{6} \Delta L I Q_{i, t}+\Delta \varepsilon_{i, t}$

The transformation into first differences enables the elimination of the separate effect $\varphi_{i}$, and also using the stated lags allows for the orthogonal conditions between $\varepsilon_{i, t}$ and explanatory variables (including $L E V_{i, t-1}$ ), by which not only their correlations but also the implied endogeneity is removed.

However, Blundell and Bond (1998) maintained that when the dependent variable is persistent - that is, there is high correlation between its values in the current and previous periods (the number of cross-sections is not very high), the GMM estimator (Arellano \& Bond, 1991) can be inefficient, given the possibility that the instruments that are created may be weak. Blundell and Bond (1998) also extended Arellano and Bond's (1991) GMM estimator, considering a system with variables at different levels and in first differences, which was known as the system GMM estimator. Accordingly, as for model (6), we use lags of first differences of explanatory variables as instrumental variables, which in turn are variables of lags of explanatory variables in model (7), also to include lag of $L E V_{i, t-1}$.

Both Arellano and Bond's (1991) and Blundell and Bond's (1998) estimators are considered appropriate only when two of the following conditions are satisfied: (i) there exist overidentifying restrictions, i.e. to determine the feasibility of instrumental variables and test the non-existence of correlation between the instrumental variables and error terms; and (ii) no second-order autocorrelation occurs in the first differences.

To determine the suitability of the GMM estimators, Sargan or Hansen test for overidentifying restrictions and Arellano-Bond test for autocorrelation are performed.

\section{Results and discussion}

\subsection{Descriptive statistics and correlation matrix}

The results of statistical description of the studied variables are presented in Table 2 . The average leverage ratio for real estate enterprises is $53.48 \%$, considerably varying from 0.0152 to 1.0571 . Commonly, firms reach the highest leverage ratio of 1 , but only in a few special cases is this figure higher than 1, implying the negative equity having 
been used up due to poor business performance and the need for debt for compensation. Accordingly, we maintain this ratio to well reflect the state of real estate sector during its financial distress.

\section{Table 2}

Statistical description of variables

\begin{tabular}{ccccc}
\hline Variable & Mean & Max & Min & Std. dev. \\
\hline LEV & 0.5348 & 1.0571 & 0.0152 & 0.1979 \\
SIZE & 27.7254 & 31.9588 & 25.3606 & 1.2942 \\
PROF & 0.0652 & 0.6090 & -0.4786 & 0.0859 \\
TANG & -0.6999 & -0.0244 & -3.6254 & 0.5467 \\
GROW & 0.2280 & 5.0751 & -0.4033 & 0.5380 \\
RISK & 0.0656 & 0.6351 & 0.0125 & 0.0622 \\
LIQ & 2.9355 & 42.7145 & 0.2326 & 4.3840 \\
\hline
\end{tabular}

Table 3 reports the estimated results for mutiple coefficients of correlations between the explanatory variables, which are not high (lower than 0.3 ). Thus, it is less likely for multicolinearity to occur during the performance of regression models.

\section{Table 3}

Correlation matrix of variables

\begin{tabular}{ccccccccc}
\hline & LEV $_{i, t}$ & LEV $_{i, t-1}$ & SIZE $_{i, t}$ & PROF $_{i, t}$ & TANG $_{i, t}$ & GROW $_{i, t}$ & RISK $_{i, t}$ & LIQ $_{i, t}$ \\
\hline LEV $_{i, t}$ & 1.0000 & & & & & & & \\
LEV $_{i, t-1}$ & $0.8407 * * *$ & 1.0000 & & & & & & \\
SIZE $_{i, t}$ & $0.2383 * * *$ & $0.2237 * * *$ & 1.0000 & & & & & \\
PROF $_{i, t}$ & -0.0681 & 0.0788 & -0.0189 & 1.0000 & & & & \\
TANG $_{i, t}$ & $0.2012 * * *$ & $0.1297 *$ & 0.0412 & $-0.1807 * * *$ & 1.0000 & & \\
GROW $_{i, t}$ & $0.1974 * * *$ & -0.0313 & 0.0506 & $0.1069 *$ & -0.0998 & 1.0000 & & \\
RISK $_{i, t}$ & $-0.2155^{* * *}$ & $-0.2247 * * *$ & -0.074 & 0.0656 & $-0.2381 * * *$ & 0.0706 & 1.0000 & \\
LIQ $_{i, t}$ & $-0.3088^{* * *}$ & $-0.2430 * * *$ & -0.0707 & -0.0141 & -0.015 & -0.0436 & $0.1229 * *$ & 1.0000 \\
\hline
\end{tabular}

Note: *,*, and $* * *$ denote significance levels of $10 \%, 5 \%$, and $1 \%$ respectively. 


\subsection{Comparison of the two kinds of models' results}

The results of the two kinds of models are performed in Table 4, which indicates that F-statistic and Wald tests are all significant and approves the appropriateness of the variables in use.

Given the static models, LM and Hausman tests both reject the null hypothesis, which shows the existence of separate effects and their correlations with the explanatory variables. Hence, among the static ones FEM is the most suitable model, indicating that: (i) firm size and growth rate positively impact leverage ratio; (ii) liquidity negatively impacts the leverage ratio; and (iii) profitability, tangible assets, and risk have no effects on the leverage ratio.

Regarding the GMM estimators, Sargan and Hansen tests accept the null hypothesis, implying the proper use of instrumental variables. The autocorrelation test, furthermore, demonstrates no occurrence of second-order aucorrelations and thereby credibility of the GMM estimation. Yet, a strong correlation is held between $L E V_{i, t}$ and $L E V_{i, t-1}$, along with the correlation coefficient of 0.8407 (Table 3), confirming that Blundell and Bond's (1998) estimator is more favored than Arellano and Bond's (1991). In addition, its results can be used to represent those achieved from dynamic models, suggesting that: (i) Leverage ratio of previous year and growth rate positively affect leverage ratio; (ii) profitability and risk negatively affect the leverage ratio; and (iii) size, tangible assets, and liquidity have no impact on the leverage ratio.

Clearly, the results of the two kinds of models differ markedly, and the research only employing the static ones may end in biased findings on both the estimated coefficients and significance levels.

The static and dynamic models have in common the results on the impact of TANG (no impact) and GROW (positive impact) on leverage ratio, whereas those on the other factors' are opposite. Moreover, the dynamic models further detail the previous year's ratio with its influence on that of the current one. 


\section{Table 4}

Regression results for static and dynamic models

Dependent variables: $\mathrm{LEV}_{\text {it }}$

\begin{tabular}{|c|c|c|c|c|c|}
\hline & \multicolumn{3}{|c|}{ Static models } & \multicolumn{2}{|c|}{ Dynamic models } \\
\hline & OLS & REM & FEM & GMM (1991) & GMM (1998) \\
\hline $\mathrm{LEV}_{\mathrm{i},-1}$ & \# & \# & $\#$ & $0,477 * * *$ & $0,548 * * *$ \\
\hline $\mathrm{SIZE}_{\mathrm{i}, \mathrm{t}}$ & $0.0292 * * *$ & $0.0471 * * *$ & $0.127 * * *$ & 0.025 & 0.009 \\
\hline $\mathrm{PROF}_{\mathrm{i}, \mathrm{t}}$ & -0.118 & -0.0843 & -0.0441 & $-0.436^{* * *}$ & $-0.685^{* * *}$ \\
\hline $\mathrm{TANG}_{\mathrm{i}, \mathrm{t}}$ & $0.0607 * * *$ & 0.028 & 0.022 & $0.0528 * * *$ & 0.0255 \\
\hline $\mathrm{GROW}_{\mathrm{i}, \mathrm{t}}$ & $0.0766^{* * *}$ & $0.0355 * * *$ & $0.0362 * * *$ & $0.186^{* * *}$ & $0.228 * * *$ \\
\hline RISK $_{i, t}$ & $-0.445 * *$ & -0.202 & 0.345 & $-0.674 * *$ & $-1.259 * * *$ \\
\hline $\mathrm{LIQ}_{\mathrm{i}, \mathrm{t}}$ & $-0.0121 * * *$ & $-0.00734 * * *$ & $-0.00702 * * *$ & $-0.00332 * * *$ & 0.004 \\
\hline F-statistic & $13.52 * * *$ & & $8.74 * * *$ & & \\
\hline Wald $(\chi 2)$ & & $54.66 * * *$ & & $11514.34 * * *$ & $160.53^{* * *}$ \\
\hline $\operatorname{LM}\left(\chi^{2}\right)$ & & $250.09 * * *$ & & & \\
\hline $\operatorname{Hausman}(\chi 2)$ & & & $16.96 * * *$ & & \\
\hline Sargan & & & & 39.44 & 29.22 \\
\hline Hansen & & & & & 24.81 \\
\hline $\operatorname{AR}(1)$ & & & & $-2.706^{* * *}$ & $-2.17 * *$ \\
\hline $\operatorname{AR}(2)$ & & & & -1.5459 & -1.51 \\
\hline
\end{tabular}

Note: $* * *$, and $* * *$ denote significance levels of $10 \%, 5 \%$, and $1 \%$ respectively.

The results of the two kinds of models, regarding the magnitudes of $\beta$, also differ enormously. Estimated coefficients of the factors expected to influence leverage ratio in the dynamic models escalate many times as sharply as those in the static ones in terms of absolute magnitudes. These involve RISK, GROW, and PROF, whose coefficients increase from $0.345,0.036$, and 0.044 to $1.259,0.228$, and 0.685 respectively during the shift in measures from static to dynamic models. Meanwhile, coefficients of those 
without impact (SIZE and LIQ) decrease from 0.127 and 0.007 to 0.009 and 0.004 respectively, except for TANG with no much change.

In short, the comparison of the attained results indicates significant differences between the two kinds of models, and combining such with analyses of the essence of each measure using a short period of time $(t=6$ years) allows for our selection of Blundell and Bond's (1998) estimator as the optimum that can be applied to the case of Vietnam's real estate sector. This outcome is agreeable with Flannery and Hankins (2013), who compared the dynamic models in the domain of corporate finance and also in view of capital structure.

\subsection{Discussion}

While the negative impact is exerted by PROF and RISK, GROW positively affects leverage ratio, and this implies that the pecking order theory dominates others in its explaining capital structure decisions among real estate firms. These results are compatible with those suggested by Bond and Scott (2006) and Tongkong (2012).

As discussed above, because PROF negatively impacts leverage ratio, we argue that well-performing firms prioritize the use of retained earnings to finance their own activities. These firms, to put it differently, are characterized by less external financing demand and over time use the earnings for debt payment and maintain business performance with a low leverage ratio.

Still, when more investments are needed in the real estate domain, which is as often associated with capital-consuming projects, total assets growth will experience its high speed, accompanied by high financial growth and thus involving the internal capital sources insufficient to ensure the growth rates. Consequently, there is a need for external financing, which, according to the pecking order theory, are followed by external loans. This pinpoints the rationality of the positive impact of GROW on leverage ratio-that is, the higher the growth rates, the more debt they require, or in other words, real estate firms take advantage of loans supposed to facilitate their development.

Risk, measured by variance in returns, is found to negatively affect leverage ratio. This is logical as in the real estate sector, which requires a large amount of operating cash flows. A high variance in returns signifies unstable flows as reflected by business performance, which would impede firms' financing processes. 
Interestingly, firm size and tangible assets have a positive yet statistically insignificant impact on leverage ratio, which deviates from most of the empirical research on capital structure having been conducted both domestically and internationally. Nevertheless, such complies with the findings of Lim et al. (2012), who empirically studied 44 Chinese real estate companies over the 2008-2011 period.

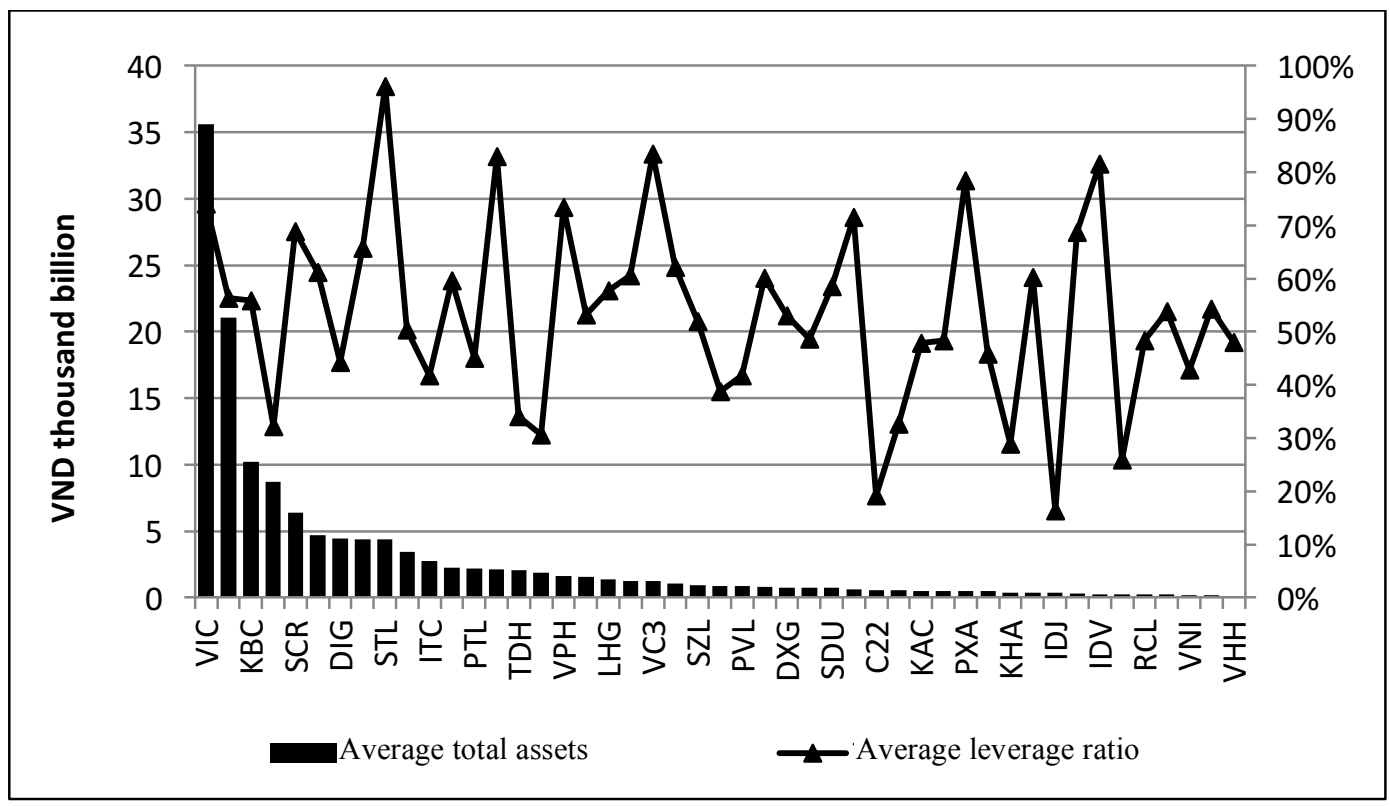

Figure 1. Average total assets and leverage ratio of real estate enterprises (2008-2013)

The data series sorted in descending order in Figure 1 indicate no obvious correlation between size and average leverage ratio and a high variance in the leverage ratio across the firms irrespective of their size. In the Vietnamese real estate landscape this is particularly justifiable owing to the bleak market in recent years but also the dissonance of supply and demand, bringing about an increase in inventories and unsold real estate products. In addition, real estate outstanding loans and non-performing loans are a current hindrance to banking activities, and most non-performing loans are in line with the real estate serving as collateral. This implies that the use of real estate as collateral no longer has positive effect as capital recovery through this kind of collateral has not been highly likely, especially in the phase of stagnation and decline over the past five or more years. 
It is worth noting that a positive impact is also produced by LIQ; however, its result is not statistically significant, which can be explained in the similar fashion as are SIZE and TANG. Real estate inventories make up a large proportion of current assets, and no additional real benefits are gained by real estate as collateral in external financing from the market.

Furthermore, coefficient $\delta=0.548$ corresponding to coefficient of adjustment $\alpha=$ $0.452(\delta=1-\alpha)$, which is below the average, shows that the speed of adjustment to the target capital structure is not astonishingly high, and the capital structure of Vietnam's real estate enterprises remains rather distant from the optimal one. Compared to the case of Thailand ( $\alpha=0.63$, as found by Tongkong [2012]), Vietnam's enterprises reflect a lower speed of adjustment, and the process must be rougher and costlier.

\section{Concluding remarks and recommendations}

\subsection{Conclusion}

The study has performed an analysis of multiple factors affecting the capital structure of Vietnam's real estate enterprises based on both static and dynamic estimators. With the data of 47 HOSE- and HNX-listed firms over the period of 2008-2013, its empirical findings have demonstrated a great difference between the kinds of models, and specifically, the dynamic ones offer more information as these succeed in addressing the dynamism of capital structure decisions. Above all, Blundell and Bond's (1998) estimator is found to be an optimal choice for such an empirical analysis of the real estate sector in Vietnam.

As such, three determinants of real estate enterprises' capital structure comprise growth rate (positive impact), profitability (negative impact), and risk (negative impact). In contrast, firm size, tangible assets, and liquidity do not have effects on leverage ratio. The impact of these factors also hints that the pecking order theory surpasses the tradeoff theory in clarifying firms' capital structure decisions.

Additionally, as indicated by the results, the speed of adjustment to the optimal capital structure is not astonishingly high $(\alpha=0.452)$, implying that firms' adjustment costs are relatively large, which results in the enterprises operating rather distantly from their targets. 


\subsection{Recommendations}

A few recommendations grounded on the research findings can be discussed as follows:

The fact that firm size does not affect leverage ratio, which in turn is positively and negatively impacted by growth rate and level of risk respectively, means that SMEs, exhibiting high growth potential and stable returns and/or low risk, gain more advantage in accessing external finance. Thus, in case of low leverage ratio, these firms shall aggressively foster their own use of loans to capitalize on the tax shield, which functions as a precondition for corporate development.

Besides firm size without any impact, the study has pointed to tangible assets and liquidity, both of which have no effects on leverage ratio. Thus, if large-sized firms possess a range of tangible assets and high liquidity, this does not mean that they will get better advantage in capital funding than SMEs. Empirical results have also indicated that fixed assets, chiefly real estate, often used as collateral, no longer play a key part under the pressure of non-performing loans recorded within the banking system. This fact does not necessarily deny the importance of collateral, but stresses that the collateral should not be regarded as a prerequisite for loans since banks in their lending is not to seize collateral but to explore in what case/manner loans are used and whether the use is effective, and so forth, thereby increasing the chances for their capital recovery and escalating returns. For this reason, firms' success in capital borrowing lies in the feasibility of their ongoing projects, realized by proper design of real estate projects and well-trained experts in finance and economics, who exercise effective control of investment plans for further loan requirements.

Not only do firm-specific factors influence a firm's leverage ratio, as has been proved by empirical findings, but the ratio is also impacted by external ones such as inflation, GDP, capital market, and characteristics of relevant industry, all of which, however, have not been addressed in our study. In addition, we merely focus on the total debt ratio, not having examined short- and long-term ones that detail the manner of capital structure decisions adopted among real estate firms. This can be viewed as another suggestion for future studies 


\section{References}

Antoniou, A., Guney, Y., \& Paudyal, K. (2008). The determinants of capital structure: Capital marketoriented versus bank-oriented institutions. Journal of Financial and Quantitative Analysis, 43(1), 59-92.

Arellano, M., \& Bond, S. (1991). Some tests of specification for panel data: Monte Carlo evidence and an application to employment equations. The Review of Economic Studies, 58(2), 277-297.

Baltagi, B. (2008). Econometric analysis of panel data (Vol. 1). NJ: John Wiley \& Sons.

Blundell, R., \& Bond, S. (1998). Initial conditions and moment restrictions in dynamic panel data models. Journal of Econometrics, 87(1), 115-143.

Bond, S. A., \& Scott, P. J. (2006). The capital structure decision for listed real estate companies. http://dx.doi.org/10.2139/ssrn.876429

Booth, L., Aivazian, V., Demirguc-Kunt, A., \& Maksimovic, V. (2001). Capital structures in developing countries. The Journal of Finance, 56(1), 87-130.

Chen, J. J. (2004). Determinants of capital structure of Chinese-listed companies. Journal of Business Research, 57(12), 1341-1351.

Chikolwa, B. (2011). Investigating the capital structure of A-REITs. Journal of Real Estate Literature, 19(2), 391-411.

DeAngelo, H., \& Masulis, R. W. (1980). Optimal capital structure under corporate and personal taxation. Journal of Financial Economics, 8(1), 3-29.

Flannery, M. J., \& Hankins, K. W. (2013). Estimating dynamic panel models in corporate finance. Journal of Corporate Finance, 19, 1-19.

Frank, M. Z., \& Goyal, V. K. (2009). Capital structure decisions: Which factors are reliably important? Financial Management, 38(1), 1-37.

Gaud, P., Jani, E., Hoesli, M., \& Bender, A. (2005). The capital structure of Swiss companies: An empirical analysis using dynamic panel data. European Financial Management, 11(1), 51-69.

Getzmann, A., Lang, S., \& Spremann, K. (2010). Determinants of the target capital structure and adjustment speed: Evidence from Asian capital markets. Retrieved March 2012 from http://www.uibk.ac.at/ibf/sonstiges/seminar/targetcapitalstructureasia.pdf

Graham, J. R., \& Leary, M. T. (2011). A review of empirical capital structure research and directions for the future. Annual Review of Financial Economics, 3.

Hall, G., Hutchinson, P., \& Michaelas, N. (2000). Industry effects on the determinants of unquoted SMEs' capital structure. International Journal of the Economics of Business, 7(3), 297-312.

Jensen, M. C. (1986). Agency cost of free cash flow, corporate finance, and takeovers. American Economic Review, 76(2), 323-329. 
Le, D. C. (2013). Factors affecting the capital structure planning of Vietnamese financial managers (in Vietnamese). Journal of Development and Integration, 9(19), 22-28.

Le, P. D., \& Nguyen, T. T. T. (2013). Factors influencing financial structure of building materials firms. Journal of Economic Development, 271, 51-64.

Lim, T. C., Zhao, D., \& Chai, R. (2012). Capital structure of real estate firms in Chinese stock market. International Journal of Management Sciences and Business Research, 1(9), 75-85.

Modigliani, F., \& Miller, M. H. (1958). The cost of capital, corporation finance and the theory of investment. The American Economic Review, 48(3), 261-297.

Myers, S. C. (1984). The capital structure puzzle. The Journal of Finance, 39(3), 574-592.

Myers, S. C., \& Majluf, N. S. (1984). Corporate financing and investment decisions when firms have information that investors do not have. Journal of Financial Economics, 13(2), 187-221.

Ooi, J. (1999). The determinants of capital structure evidence on UK property companies. Journal of Property Investment \& Finance, 17(5), 464-480.

Ozkan, A. (2001). Determinants of capital structure and adjustment to long run target: Evidence from UK company panel data. Journal of Business Finance \& Accounting, 28(1-2), 175-198.

Rajan, R. G., \& Zingales, L. (1995). What do we know about capital structure? Some evidence from international data. The Journal of Finance, 50(5), 1421-1460.

Titman, S., \& Wessels, R. (1988). The determinants of capital structure choice. The Journal of Finance, 43(1), 1-19.

Tongkong, S. (2012). Key factors influencing capital structure decision and its speed of adjustment of Thai listed real estate companies. Procedia-Social and Behavioral Sciences, 40, 716-720.

Tran, D. K. N., \& Ramachandran, N. (2006). Capital structure in small and medium-sized enterprises: The case of Vietnam. ASEAN Economic Bulletin, 23(2), 192-211.

Vo. T. T. A., \& Bui, P. N. K. (2012). Factors affecting corporate financial structure: An empirical study on HOSE-listed firms in manufacturing industry (in Vietnamese). Journal of Economic Development, No. 260, 33-40.

Wald, J. (1999). Capital structure with dividend restrictions. Journal of Corporate Finance, 5(2), 193-208.

Westgaard, S., Eidet, A., Frydenberg, S., \& Grosås, T. C. (2008). Investigating the capital structure of UK real estate companies. Journal of Property Research, 25(1), 61-87. 